Article

\title{
Stress-Corrosion Cracking Behaviour of Lean-Duplex Stainless Steels in Chloride/Thiosulphate Environments
}

\author{
Federica Zanotto ${ }^{1,2, *}$, Vincenzo Grassi ${ }^{1}$, Andrea Balbo ${ }^{1}$ (D), Cecilia Monticelli ${ }^{1}$ (D) \\ and Fabrizio Zucchi ${ }^{1}$ \\ 1 "Aldo Daccò" Corrosion and Metallurgy Study Centre, University of Ferrara, Via G. Saragat 4A, \\ 44122 Ferrara, Italy; vincenzo.grassi@unife.it (V.G.); andrea.balbo@unife.it (A.B.); \\ cecilia.monticelli@unife.it (C.M.); zhf@unife.it (F.Z.) \\ 2 Terra\&AcquaTech Laboratory, University of Ferrara, Via Saragat 1, 44122 Ferrara, Italy \\ * Correspondence: zntfrc@unife.it; Tel.: +39-0532-45-5195
}

Received: 1 March 2018; Accepted: 2 April 2018; Published: 4 April 2018

check for updates

\begin{abstract}
The stress-corrosion cracking (SCC) behaviour of two lean-duplex stainless steels (DSS 2304 and LDSS 2404) was studied by slow strain-rate tests (SSRT) in $20 \% \mathrm{NaCl}$ solution at $80{ }^{\circ} \mathrm{C}(\mathrm{pH}$ about 6) and in NACE TM-0177 solution at $25^{\circ} \mathrm{C}(\mathrm{pH} 2.7)$, both in the absence and in the presence of thiosulphate ions $\left(\mathrm{S}_{2} \mathrm{O}_{3}{ }^{2-}\right)$. The SCC susceptibility of the two alloys was compared to that of LDSS 2101 investigated in a previous study. LDSS 2404 was always immune to SCC, while DSS 2304 (and LDSS 2101) suffered this corrosion form at specific concentrations. The high SCC resistance of DSS 2404 in both environments was connected to its high Mo content, while the significant SCC susceptibility of LDSS 2101 in NACE TM-0177 solution was likely due to the high Mn content of the alloy.
\end{abstract}

Keywords: lean-duplex stainless steel; slow strain-rate testing; stainless steel; stress corrosion; sulphide cracking

\section{Introduction}

Duplex stainless steels (DSS) are very interesting materials due to the favourable combination of their mechanical properties, weldability and corrosion resistance in various environments. These characteristics support their use in various fields, from the paper to the petrochemical industries and from the construction sector to nuclear energy production [1]. Compared to conventional DSS (i.e., DSS 2205), lean-duplex stainless steels (LDSS) are grades with lower nickel (i.e., LDSS 2101, LDSS 2404) and/or molybdenum (i.e., DSS 2304) content [2,3]. Their employment is considered when they can lead to economical benefits in the design and maintenance of industrial plants or civil construction. Oil and gas equipment often operates in contact with chloride- and sulphide-rich media. The use of LDSS is proposed mostly on the basis of their pitting and stress-corrosion cracking (SCC) resistance in these environments [4]. Many papers deal with the SCC resistance of DSS 2205 [5-9] and superduplex stainless steels [10-13] in hydrogen sulphide $\left(\mathrm{H}_{2} \mathrm{~S}\right)$ media. By contrast, few data are reported about the SCC behaviour of LDSS in these media. Johansson et al. [4] showed that no SCC was observed at $\mathrm{H}_{2} \mathrm{~S}$ levels up to 0.15 bar for LDSS 2101 and 1 bar for DSS 2304 in NACE TM-0177. Ruel et al. [14] found that DSS 2304 had a higher SCC resistance in comparison to LDSS 2101 in $50 \mathrm{~g} / \mathrm{L} \mathrm{NaCl,} 5 \mathrm{~g} / \mathrm{L}$ $\mathrm{CH}_{3} \mathrm{COONa}$, at $\mathrm{pH} 2.8$, with $50 \% \mathrm{H}_{2} \mathrm{~S}$, at the temperature of $20^{\circ} \mathrm{C}$. They also suggested that $\mathrm{Mn}$ has a negative effect on SCC resistance, while $\mathrm{N}$ has a positive one. The SCC susceptibility of LDSS 2404 in environments containing $\mathrm{H}_{2} \mathrm{~S}$ has not yet been investigated. Therefore, the study of the corrosion 
performances of LDSS in simulated oil and gas conditions is reputedly quite important. DSS 2304 was the first commercialized lean duplex. It was developed as a $\sigma$-free and low-cost grade, due to the Mo savings (Mo mass \% around 0.3\%) [1]. Among LDSS currently on the market, the 2101 grade is a suitable candidate for application in the oil and gas industry, in particular for mild well conditions and topside components [4], where it can satisfactorily substitute standard austenitic grades [15,16]. On the contrary, LDSS 2404 is a recently introduced Mo- and N-containing LDSS grade, designed as an economical alternative to the 2205 grade [17]. In our laboratory, we studied the corrosion resistance of LDSS 2101 extensively [18-21]. In particular, we focused on its SCC susceptibility in chloride solutions containing thiosulphate ions $\left(\mathrm{S}_{2} \mathrm{O}_{3}{ }^{2-}\right)[18,20]$. The approach to add $\mathrm{S}_{2} \mathrm{O}_{3}{ }^{2-}$ instead of $\mathrm{H}_{2} \mathrm{~S}$ gas in acid salt solutions in order to simulate the aggressiveness of sour well environments was suggested by Tsujikawa et al. [22], in order to study the pitting and SCC susceptibility of alloys in simulated well conditions, while minimizing the health hazards during laboratory tests and reducing the cost of equipment required to operate under safety conditions. In particular, they found that materials susceptible to SCC in $\mathrm{H}_{2} \mathrm{~S}$-containing solutions exhibited the same behaviour in the presence of $\mathrm{S}_{2} \mathrm{O}_{3}{ }^{2-}$ [23]. Since $\mathrm{S}_{2} \mathrm{O}_{3}{ }^{2-}$ is thermodynamically metastable, it may undergo disproportion and reduction reactions on the alloy surface to yield elemental $\mathrm{S}$, which can be further reduced to $\mathrm{H}_{2} \mathrm{~S}$, depending on the solution $\mathrm{pH}$ and on the alloy corrosion potential [24]. As an example, $\mathrm{H}_{2} \mathrm{~S}$ forms spontaneously on a carbon steel surface under free-corrosion conditions in acidic $\mathrm{S}_{2} \mathrm{O}_{3}{ }^{2-}$ solutions [25]. On the contrary, in the same solutions a continuous surface scratching is needed to detect $\mathrm{H}_{2} \mathrm{~S}$ gas formation on a 316-type stainless steel [23], because scratching causes a shift of the alloy-corrosion potential, into the $\mathrm{H}_{2} \mathrm{~S}$ stability domain.

Some research studies [26-28] helped to clarify the detrimental effect of $\mathrm{S}_{2} \mathrm{O}_{3}{ }^{2-}$ dissolved in aqueous solutions on the corrosion resistance of stainless steels. They showed that adsorbed sulphur monolayers can form on $\mathrm{Fe}, \mathrm{Ni}$, and $\mathrm{Cr}$, due to $\mathrm{S}_{2} \mathrm{O}_{3}{ }^{2-}$ reduction on the metal surface, also under potential $\mathrm{pH}$ conditions in which usual Pourbaix diagrams predict no metal sulphide stability [26]. Moreover, they demonstrated that in neutral chloride solution, $\mathrm{S}_{2} \mathrm{O}_{3}{ }^{2-}$ exerts a deleterious effect on the pitting resistance of a Fe-17Cr alloy on which the $\mathrm{S}_{2} \mathrm{O}_{3}{ }^{2-}$ reduction occurs only in correspondence of bare alloy regions, leading to the formation of sulphide islands incorporated into the oxide layer and/or sulphur adsorbed at the metal/oxide interface [27]. Adsorbed sulphur is reported to inhibit repassivation in correspondence of passive film flaws formed by chloride ions, thereby affecting the corrosion resistance of stainless steels [26,29]. Depending on the conditions of the slow strain-rate tests (SSRT), in particular at sufficiently acidic $\mathrm{pH}, \mathrm{S}_{2} \mathrm{O}_{3}{ }^{2-}$ addition in chloride solutions may produce both $\mathrm{H}_{2} \mathrm{~S}$ and $\mathrm{S}$, which can inhibit repassivation and catalyse the ingress of hydrogen in the alloys thus inducing sulphide-induced SCC (S-SCC) in stainless steels [28].

In our preceding work [18], SSRT were performed on LDSS 2101 during exposures to $20 \% \mathrm{NaCl}$ solution at $80{ }^{\circ} \mathrm{C}$ (near neutral $\mathrm{pH}$ ) and to standard NACE TM- 0177 solution at $25^{\circ} \mathrm{C}$ and $\mathrm{pH} 2.7$, in the absence and in the presence of $\mathrm{S}_{2} \mathrm{O}_{3}{ }^{2-}$ at various concentrations. LDSS 2101 was susceptible to SCC in $20 \% \mathrm{NaCl}$ solution at $80^{\circ} \mathrm{C}$ in the presence of $\mathrm{S}_{2} \mathrm{O}_{3}{ }^{2-}$ at $10^{-3} \mathrm{M}$. However, the susceptibility decreased by increasing $\mathrm{S}_{2} \mathrm{O}_{3}{ }^{2-}$ concentration, due to a significant selective dissolution at the expense of the ferrite phase. The corrosion potential values recorded during the tests were at the limit of the $\mathrm{H}_{2} \mathrm{~S}$ stability domain [23] and well within the stability domains of sulphur adsorbed on $\mathrm{Fe}, \mathrm{Ni}$ and $\mathrm{Cr}$ [26]. Thus, at high $\mathrm{S}_{2} \mathrm{O}_{3}{ }^{2-}$ concentration, the selective corrosion of the ferrite phase, catalysed by adsorbed sulphur and stimulated by the galvanic coupling with the nobler austenite phase became competitive with SCC, reducing the SCC susceptibility of LDSS 2101, likely through crack tip blunting [30]. In NACE TM-0177 solution at $25^{\circ} \mathrm{C}$ and $\mathrm{pH}$ 2.7, LDSS 2101 was susceptible to SCC even at $10^{-4} \mathrm{M}$ $\mathrm{S}_{2} \mathrm{O}_{3}{ }^{2-}$ and the SCC susceptibility increased at increasing $\mathrm{S}_{2} \mathrm{O}_{3}{ }^{2-}$ concentration up to $10^{-2} \mathrm{M}$. Under these acidic conditions, the recorded corrosion potential values were significantly more negative than the equilibrium potentials of $\mathrm{S}_{2} \mathrm{O}_{3}{ }^{2-}$ reduction to both $\mathrm{S}$ and $\mathrm{H}_{2} \mathrm{~S}$ [24], suggesting that S-SCC was the predominant failure mechanism, particularly at higher $\mathrm{S}_{2} \mathrm{O}_{3}{ }^{2-}$ concentrations. Our research studies [18] and other literature results [4] showed that, in NACE TM-0177 solution containing $\mathrm{S}_{2} \mathrm{O}_{3}{ }^{2-}$ 
or $\mathrm{H}_{2} \mathrm{~S}$, the selective dissolution of the ferrite phase became competitive with S-SCC only at higher $\mathrm{pH}$ and temperatures.

In this work, the SCC behaviour of LDSS 2404 and DSS 2304 was studied in $20 \% \mathrm{NaCl}$ solution at $80^{\circ} \mathrm{C}$ and in the standard NACE TM- 0177 solution at pH 2.7 and temperature of $25^{\circ} \mathrm{C}$, both in the absence and presence of $\mathrm{S}_{2} \mathrm{O}_{3}{ }^{2-}$, and was compared with LDSS 2101 behaviour under the same test conditions. The adopted $\mathrm{S}_{2} \mathrm{O}_{3}{ }^{2-}$ concentrations were selected on the basis of the results found for LDSS 2101 [18], so $10^{-2}$ and $10^{-1} \mathrm{M}$ were used in $20 \% \mathrm{NaCl}$ and $10^{-3}$ and $10^{-2} \mathrm{M}$ were selected for NACE TM-0177 solution at $\mathrm{pH}$ 2.7. At the end of the tests, the samples were observed under an optical microscope $(\mathrm{OM})$ to assess the morphology of the corrosive attack.

\section{Materials and Methods}

The tests were performed on LDSS 2404 and DSS 2304 stainless steels (supplied by Outokumpu S.p.A., Sheffield, United Kingdom, under annealed conditions), having the nominal chemical compositions (in mass \%) reported in Table 1 [31], where also the composition of the reference LDSS 2101 is reported. The alloy Pitting Resistance Equivalent Number (PREN) values are also reported. This index, specifically developed to predict the resistance to pitting corrosion of Stainless Steels (SS) [32], is now considered a simplified way to compare SS corrosion performances against the dependence of their chemical composition and was recently applied also to DSS [33]. Usually, it is calculated on the basis of the Cr, Mo and N contents of the SS, from the formula reported in Table 1. The PREN values predict that LDSS 2404 is the most corrosion-resistant alloy because of its high Cr, Mo and N content, while DSS 2304 and LDSS 2101 are expected to present comparable resistance to localized corrosion attack.

Table 1. Nominal chemical composition (mass \%) and PREN values (PREN $=\% \mathrm{Cr}+3.3 \times \% \mathrm{Mo}+16$ $\times \% \mathrm{~N}$ [32]) of the studied duplex stainless steels (DSS) and the reference lean-duplex stainless steel (LDSS) 2101.

\begin{tabular}{ccccccccc}
\hline DSS & C & Mn & Cr & Ni & Mo & N & Fe & PREN \\
\hline LDSS & 0.02 & 3.0 & 24 & 3.6 & 1.6 & 0.27 & bal. & 34 \\
2404 & 0.02 & - & 23 & 4.8 & 0.3 & 0.10 & bal. & 26 \\
DSS 2304 & 0.026 & \\
LDSS & 0.03 & 5.0 & 21 & 1.5 & 0.3 & 0.22 & bal. & 26 \\
2101 & & & & & & & & \\
\hline
\end{tabular}

The microstructure and the corrosion attack morphologies were documented by observations of the long transversal sections of tensile samples under an optical microscope (OM), after surface polishing with diamond pastes (up to $1 \mu \mathrm{m}$ ) and etching with Beraha's reagent.

The susceptibility to SCC was evaluated by slow strain-rate tests (SSRT), with a strain rate of $1 \times 10^{-6} \mathrm{~s}^{-1}$ [34]. Tensile samples were machined from $1.5 \mathrm{~mm}$-thick steel sheets, with their longitudinal direction parallel to the sheet lamination direction. They had an overall length of $230 \mathrm{~cm}$ and a gauge portion of $20 \times 5 \times 1.5 \mathrm{~mm}$. Their surface was ground (always parallel to the stress direction) down to 800 grit emery papers, rinsed with deionized water, and degreased with acetone. Finally, they were screened by a two-component epoxy varnish, thereby leaving only the gauge portion exposed to the solution.

For SSRT, the tensile samples were inserted in an electrochemical cell filled by the following nitrogen-deaerated and thermostated solutions:

1. $20 \% \mathrm{NaCl}$ in the absence and in the presence of sodium thiosulphate $\left(\mathrm{Na}_{2} \mathrm{~S}_{2} \mathrm{O}_{3}\right)$, at concentrations of $10^{-2}$ and $10^{-1} \mathrm{M}, \mathrm{T}=80^{\circ} \mathrm{C}$ (measured $\mathrm{pH}$ ); or

2. $5 \% \mathrm{NaCl}+0.5 \% \mathrm{CH}_{3} \mathrm{COOH}$ (the basic standard solution NACE TM-0177 [35], without $\mathrm{H}_{2} \mathrm{~S}$ gas) in the absence and in the presence of $\mathrm{Na}_{2} \mathrm{~S}_{2} \mathrm{O}_{3}$ at concentrations of $10^{-3}$ and $10^{-2} \mathrm{M}, \mathrm{T}=25^{\circ} \mathrm{C}$ (measured $\mathrm{pH}$ 2.7). 
SSRT were also performed in demineralized water at $80^{\circ} \mathrm{C}$ and in air at $25{ }^{\circ} \mathrm{C}$, as reference conditions. During each test, the stress-strain curve was recorded. Stress (in $\mathrm{MPa}$ ) is the ratio of the applied load to cross-sectional area of the gauge portion $(5 \mathrm{~mm} \times 1.5 \mathrm{~mm})$ in tensile samples, while strain is the ratio of the sample elongation to its original length, as evaluated from the relative movement of the tensile-machine crosshead. The obtained strain values are unitless, but they were expressed in percentage, as they were multiplied by 100. In parallel to stress-strain curve recording, the open circuit potential ( $\mathrm{E}_{\mathrm{OCP}}$, versus saturated calomel electrode (SCE)) values were measured. Each test was performed in triplicate.

The SCC susceptibility was evaluated by the ratio (R) between the percentage strain to fracture $\left(\varepsilon_{\mathrm{f}} \%\right)$ in the test solution and that in air (for $25^{\circ} \mathrm{C}$ tests) or water (for $80{ }^{\circ} \mathrm{C}$ tests). R values equal to or higher than 0.8 were considered an index of immunity to SCC [36].

At the end of the tests, the gauge length section of the samples were observed with an optical stereomicroscope and side surfaces were examined by an OM, after polishing and etching with Beraha's reagent, with the purpose of analysing crack initiation and morphology.

On unstressed samples with an exposed surface area of $72 \mathrm{~mm}^{2}, \mathrm{E}_{\mathrm{OCP}}$ measurements were performed during $42 \mathrm{~h}$ of immersion in the previously described aggressive solutions. After about $24 \mathrm{~h}$ of immersion, on still passive electrodes a scratch was performed by using a glass tip to verify their repassivation capability. At the end of the $42 \mathrm{~h}$ immersion, anodic polarization curves were recorded, starting from $\mathrm{E}_{\mathrm{OCP}}$, with a scan rate of $0.2 \mathrm{mV} / \mathrm{s}$.

\section{Results}

\subsection{Microstructures of the Studied Alloys}

Figure 1 shows the microstructures of DSS 2304 and LDSS 2404 in their long transversal sections, characterized by elongated austenitic grains (lighter phase) embedded in a ferritic matrix (darker phase). These microstructures are quite similar to those of LSDD 2101 [18] and are typical of rolled-duplex stainless steels. On the three alloys, the volume fraction of ferrite was always quite close to that of austenite (51 $\pm 1 \%$ ferrite and balance austenite), which corresponds to the correct phase balance for these products [37].
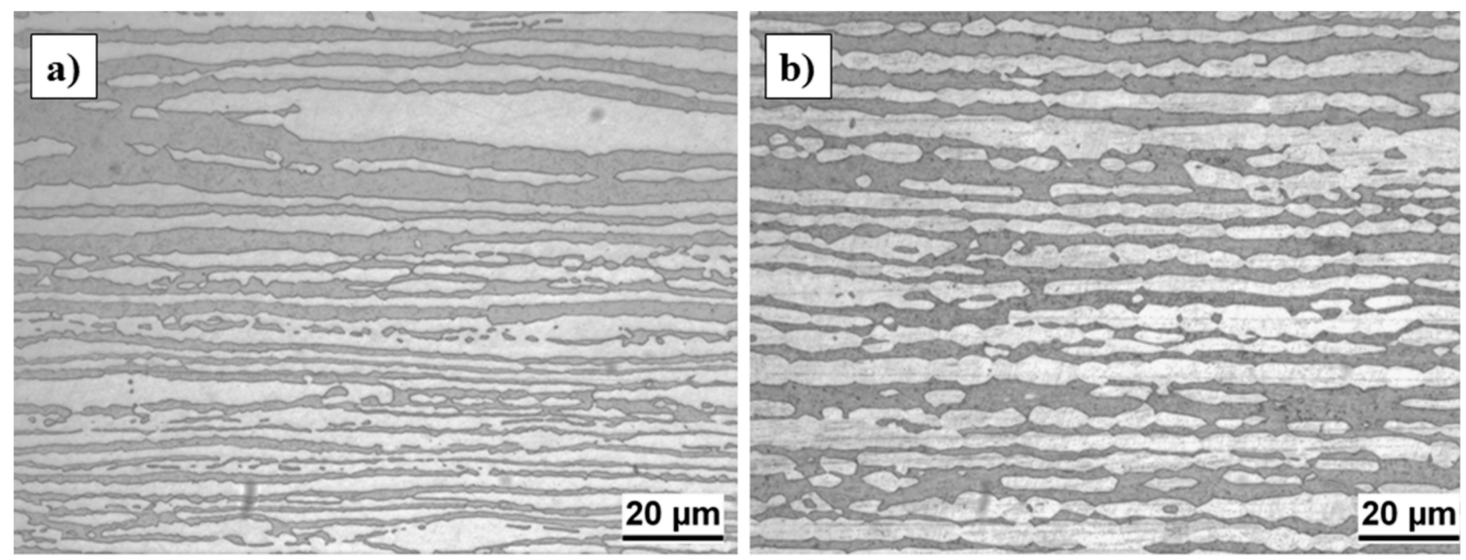

Figure 1. Microstructure of the long transversal section (parallel to load direction in slow strain-rate tests (SSRT)) of DSS 2304 (a) and LDSS 2404 (b), after etching with Beraha's reagent.

\subsection{Slow Strain-Rate Test (SSRT) Results in $20 \% \mathrm{NaCl}$ Solution at $80{ }^{\circ} \mathrm{C}$ without/with $\mathrm{S}_{2} \mathrm{O}_{3}{ }^{2-}$}

Figure 2 depicts the stress-strain curves of DSS 2304 and LDSS 2404 acquired during SSRT performed at $80{ }^{\circ} \mathrm{C}$ in water and in $20 \% \mathrm{NaCl}$ solution, in the presence and in the absence of $\mathrm{S}_{2} \mathrm{O}_{3}{ }^{2-}$ at $10^{-2}$ and $10^{-1} \mathrm{M}$ concentrations. 

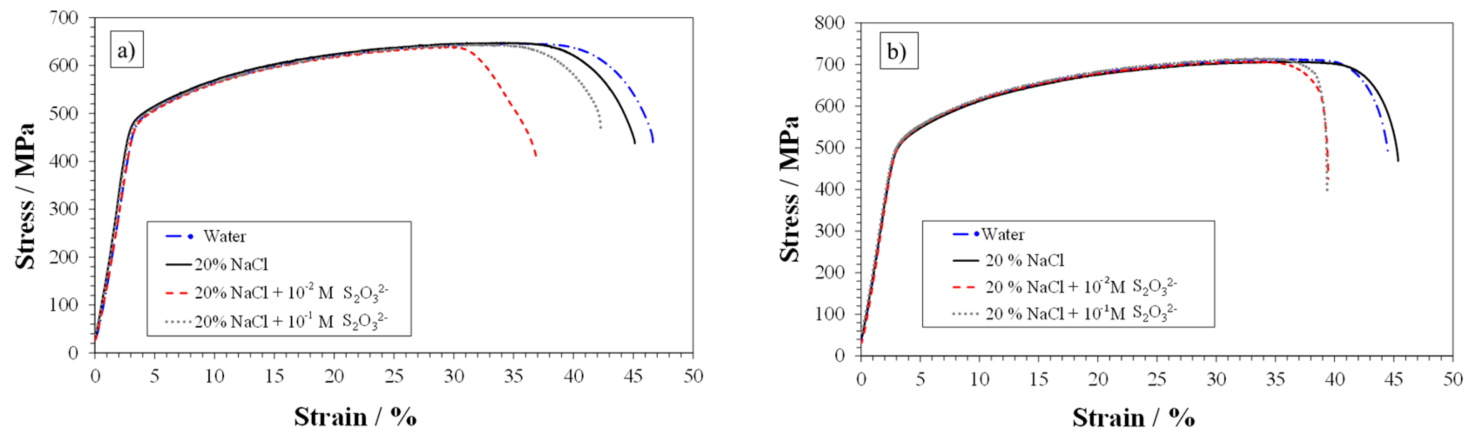

Figure 2. Stress-strain curves obtained during SSRT performed on DSS 2304 (a) and LDSS 2404 (b) at $80{ }^{\circ} \mathrm{C}$, in water and in $20 \% \mathrm{NaCl}$ solution, in the absence and in the presence of $10^{-2}$ and $10^{-1} \mathrm{M}$ $\mathrm{S}_{2} \mathrm{O}_{3}{ }^{2-}$.

The $\varepsilon_{\mathrm{f}} \%$ obtained in $20 \% \mathrm{NaCl}$ solution for both alloys were very close to those measured in water and the samples presented a ductile type fracture like that shown in Figure 3a. Thus, the alloys were not susceptible to SCC in this environment. With the addition of $10^{-2} \mathrm{M} \mathrm{S}_{2} \mathrm{O}_{3}{ }^{2-}, \varepsilon_{\mathrm{f}} \%$ of DSS 2304 decreased from 47 (obtained in water at $80{ }^{\circ} \mathrm{C}$ ) and 45 (obtained in chloride solution without $\mathrm{S}_{2} \mathrm{O}_{3}{ }^{2-}$ ) to about $37 \%$. The sample presented a fracture of a more brittle type (Figure 3b), in comparison to that shown in Figure 3a, with black corrosion products deposited on the gauge length near to the fracture surface. As expected $[9,25,38]$, iron sulphides were detected in that region by scanning electron microscopy/energy-dispersive X-ray spectroscopy (SEM-EDS) analyses.
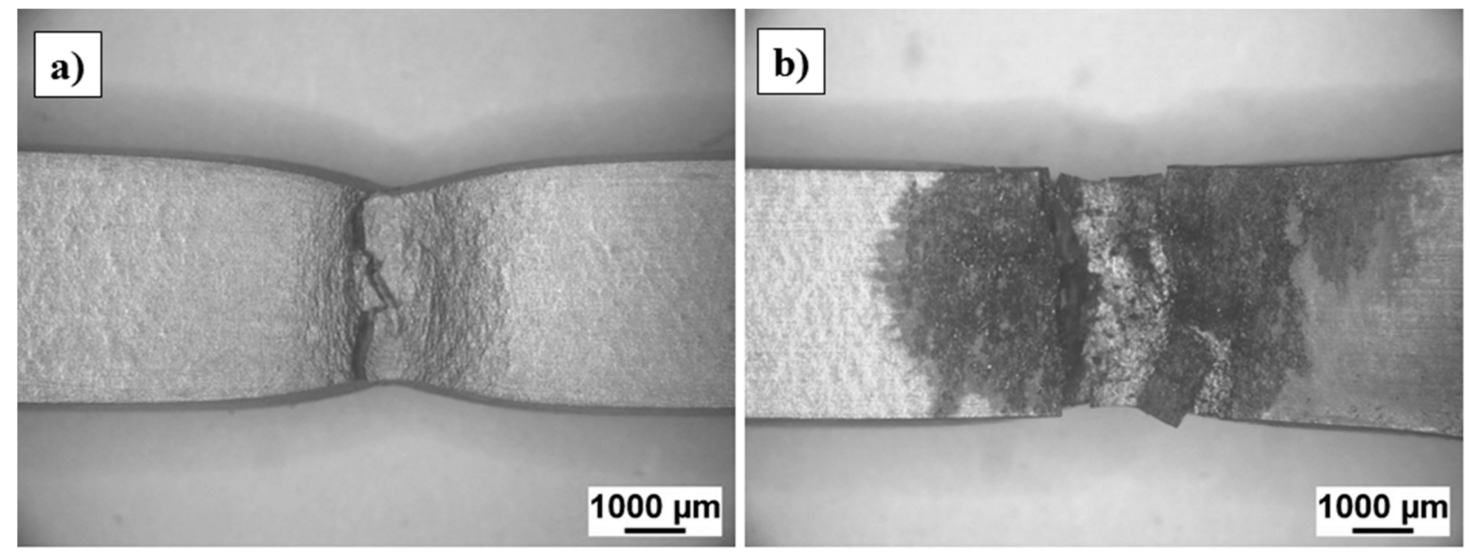

Figure 3. Macrograph acquired on the gauge length of DSS 2304 sample after SSRT in $20 \% \mathrm{NaCl}$ solution at $80^{\circ} \mathrm{C}$, in the absence (a) and in the presence of $10^{-2} \mathrm{M} \mathrm{S}_{2} \mathrm{O}_{3}{ }^{2-}(\mathbf{b})$.

The micrograph of the long transversal section (parallel to the load direction in SSRT) presented in Figure $4 \mathrm{a}$ reveals the presence of selective corrosion of the ferrite phase, with a tendency to form crack-like attacks in some points along the sample gauge length.

When $\mathrm{S}_{2} \mathrm{O}_{3}{ }^{2-}$ concentration was increased to $10^{-1} \mathrm{M}, \varepsilon_{\mathrm{f}} \%$ increased to a value close to that obtained with only chloride solution. The sample presented a moderately ductile type fracture, with black corrosion products close to the fracture region. In this case, only a selective attack of the ferrite phase can be observed by OM (Figure 4b). As already observed for LDSS 2101 [18], the increase in $\mathrm{S}_{2} \mathrm{O}_{3}{ }^{2-}$ concentration induced a significant dissolution of the ferrite phase and a reduction of attack localization and crack propagation.

In the presence of $\mathrm{S}_{2} \mathrm{O}_{3}{ }^{2-}$, the $\varepsilon_{\mathrm{f}} \%$ values of LDSS 2404 slightly decreased (Figure 2b) in comparison to that obtained in the absence of $\mathrm{S}_{2} \mathrm{O}_{3}{ }^{2-}$, but no significant differences could be detected with the variation of $\mathrm{S}_{2} \mathrm{O}_{3}{ }^{2-}$ concentration from $10^{-2}$ to $10^{-1} \mathrm{M}$. 

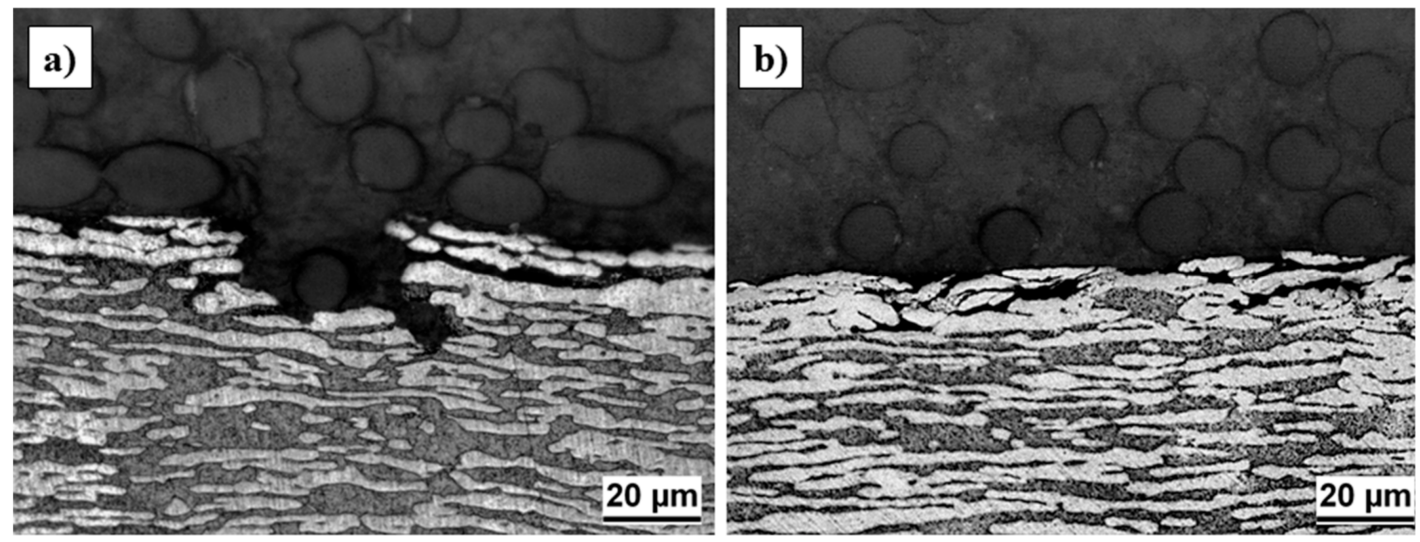

Figure 4. Micrographs of the long transversal section (parallel to the load direction) of DSS 2304 after SSRT in $20 \% \mathrm{NaCl}$ solution at $80^{\circ} \mathrm{C}$, in the presence of (a) $10^{-2}$ and (b) $10^{-1} \mathrm{M} \mathrm{S}_{2} \mathrm{O}_{3}{ }^{2-}$.

All 2404 samples tested in the presence of $\mathrm{S}_{2} \mathrm{O}_{3}{ }^{2-}$ showed a diffused corrosion attack with dark corrosion product formation (Figure 5a). The micrograph of the long transversal section of the sample tested in the presence of $\mathrm{S}_{2} \mathrm{O}_{3}{ }^{2-}$ at $10^{-2} \mathrm{M}$, reported in Figure $5 \mathrm{~b}$, only evidences a scarcely penetrating selective attack of the ferrite phase. This corrosion form characterized also the sample tested in the presence of $10^{-1} \mathrm{M} \mathrm{S}_{2} \mathrm{O}_{3}{ }^{2-}$.
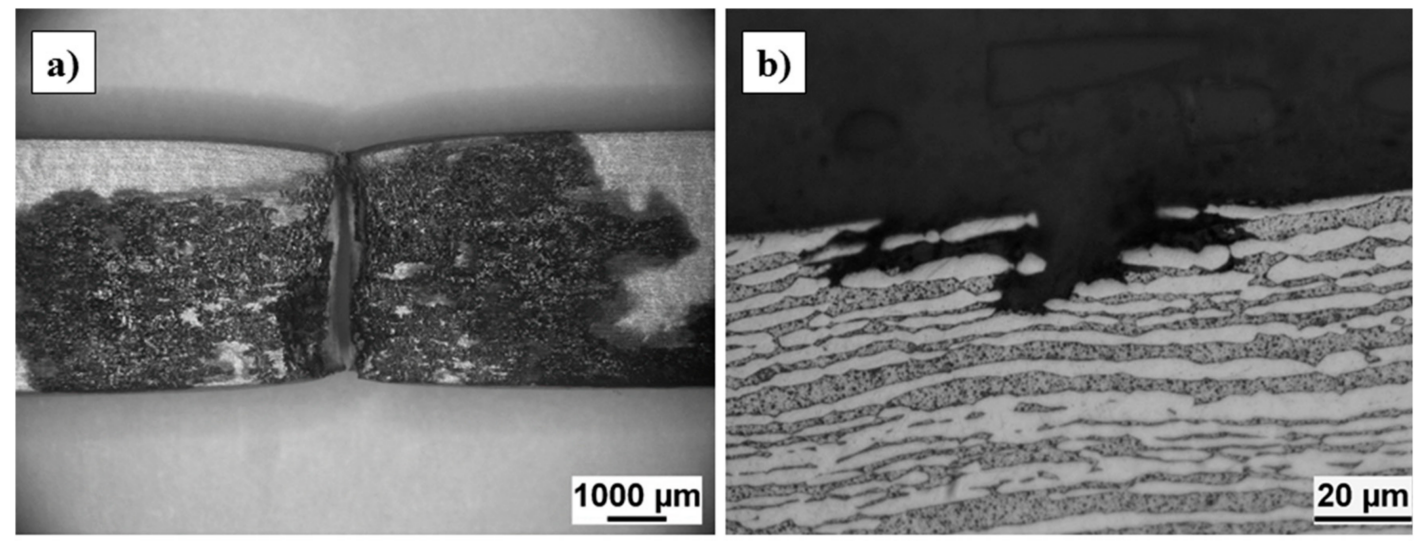

Figure 5. Macrograph (a) and micrograph of the long transversal section (parallel to the load direction) (b) acquired on the gauge length of the LDSS 2404 sample after SSRT in $20 \% \mathrm{NaCl}$ solution at $80{ }^{\circ} \mathrm{C}$, in the presence of $10^{-2} \mathrm{M} \mathrm{S}_{2} \mathrm{O}_{3}{ }^{2-}$.

Table 2 shows the average $\varepsilon_{\mathrm{f}} \%$ values from all SSRT, including the $\varepsilon_{\mathrm{f}} \%$ standard deviations.

Table 2. Average values and standard deviations of $\varepsilon_{\mathrm{f}} \%$ for DSS 2304 and LDSS 2404 obtained from SSRT at $80{ }^{\circ} \mathrm{C}$ in water and in $20 \% \mathrm{NaCl}$ solution, in the absence and in the presence of $10^{-2}$ and $10^{-1} \mathrm{M} \mathrm{S}_{2} \mathrm{O}_{3}{ }^{2-}$.

\begin{tabular}{ccc}
\hline \multirow{2}{*}{ Test Solution } & \multicolumn{2}{c}{$\boldsymbol{\varepsilon}_{\mathbf{f}} \%$} \\
\cline { 2 - 3 } & DSS 2304 & LDSS 2404 \\
\hline water $80^{\circ} \mathrm{C}$ & $47 \pm 1$ & $45 \pm 1$ \\
$20 \% \mathrm{NaCl}$ & $45 \pm 1$ & $45 \pm 2$ \\
$20 \% \mathrm{NaCl}+10^{-2} \mathrm{M} \mathrm{S}_{2} \mathrm{O}_{3}{ }^{2-}$ & $37 \pm 2$ & $39 \pm 3$ \\
$20 \% \mathrm{NaCl}+10^{-1} \mathrm{M} \mathrm{S}_{2} \mathrm{O}_{3}{ }^{2-}$ & $42 \pm 3$ & $39 \pm 3$ \\
\hline
\end{tabular}


Figure 6 presents the $\mathrm{E}_{\mathrm{OCP}}$-strain trends acquired during SSRT on DSS 2304 and LDSS 2404. In the absence of $\mathrm{S}_{2} \mathrm{O}_{3}{ }^{2-}$, the EOCP of DSS 2304 tested around -0.33 $\mathrm{V}_{\mathrm{SCE}}$, while that of LDSS 2404 showed slightly more positive values (around $-0.25 \mathrm{~V}_{\mathrm{SCE}}$ at the end of the test). These $\mathrm{E}_{\mathrm{OCP}}$ values are compatible with the formation of a protective oxide layer [28]. In the presence of $10^{-2} \mathrm{M} \mathrm{S}_{2} \mathrm{O}_{3}{ }^{2-}$, the $\mathrm{E}_{\mathrm{OCP}}$ of DSS 2304 shifted towards more negative values, reaching a plateau at $-0.47 \mathrm{~V}_{\mathrm{SCE}}$, with a further dropping to about $-0.5 \mathrm{~V}_{\mathrm{SCE}}$ at the end of the test. Conversely, in this environment, the $\mathrm{E}_{\mathrm{OCP}}$ of LDSS 2404 was initially similar to that measured in the only chloride solution (red dashed curve), but, after a few hours of the test, it dropped to values more negative than $-0.4 \mathrm{~V}_{\mathrm{SCE}}$, then reaching about $-0.45 \mathrm{~V}_{\mathrm{SCE}}$. When $\mathrm{S}_{2} \mathrm{O}_{3}{ }^{2-}$ concentration was increased to $10^{-1} \mathrm{M}$, both EOCP of DSS 2304 and that of LDSS 2404 stabilized at around $-0.43 \mathrm{~V}_{\mathrm{SCE}}$. As already noticed for LDSS 2101 [18], all $\mathrm{E}_{\mathrm{OCP}}$ values recorded in deaerated $20 \% \mathrm{NaCl}$ solution at $80{ }^{\circ} \mathrm{C}$ (measured $\mathrm{pH}$ 6) in the presence of $\mathrm{S}_{2} \mathrm{O}_{3}{ }^{2-}$ were located at the limit of the stability domain of $\mathrm{H}_{2} \mathrm{~S}$ [23] and fell well within the domain of adsorbed sulphur on the metal surfaces $[26,28]$.
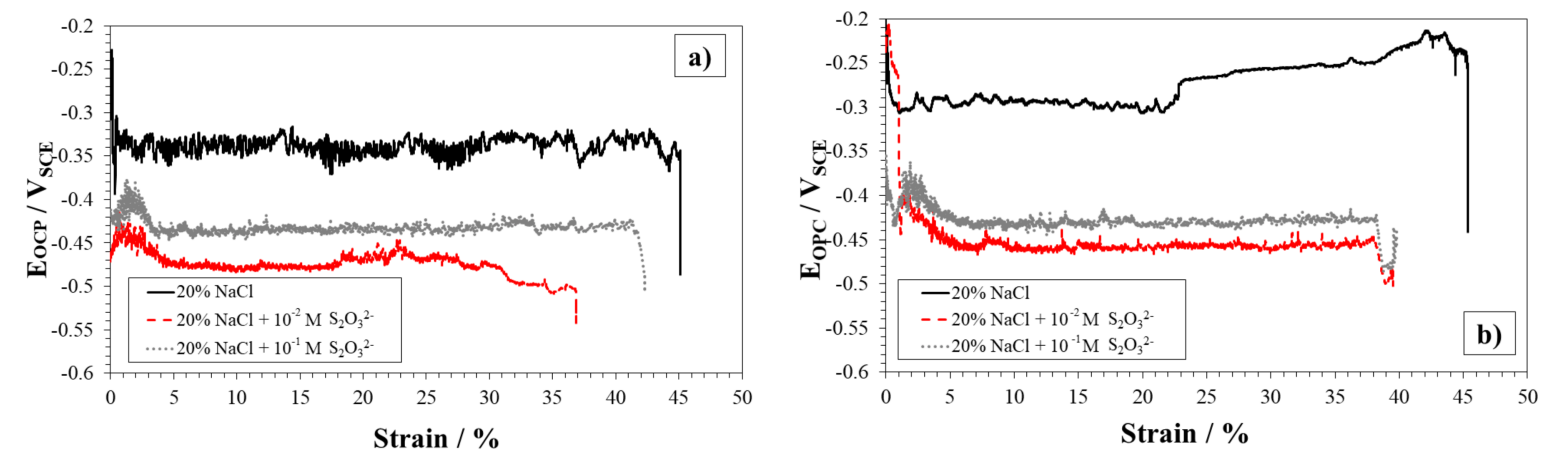

Figure 6. $\mathrm{E}_{\mathrm{OCP}}$-strain trends of DSS 2304 (a) and LDSS 2404 (b) during SSRT in $20 \% \mathrm{NaCl}$ solution at $80^{\circ} \mathrm{C}$, in the absence and presence of $10^{-2}$ and $10^{-1} \mathrm{M} \mathrm{S}_{2} \mathrm{O}_{3}{ }^{2-}$.

Figure 7 shows the $\mathrm{E}_{\mathrm{OCP}}$-time trends recorded on DSS 2304 and LDSS 2404 electrodes during static immersions of $42 \mathrm{~h}$ in $20 \% \mathrm{NaCl}$ solution at $80{ }^{\circ} \mathrm{C}$, in the absence and in the presence of $\mathrm{S}_{2} \mathrm{O}_{3}{ }^{2-}$ at $10^{-2}$ and $10^{-1} \mathrm{M}$ concentrations. In the absence of $\mathrm{S}_{2} \mathrm{O}_{3}{ }^{2-}$, both alloys exhibited fast oscillations of $\mathrm{E}_{\mathrm{OCP}}$ around $-0.1 /-0.15 \mathrm{~V}_{\mathrm{SCE}}$ values and a scratch on the electrode surface after $24 \mathrm{~h}$ of immersion produced only a spike to about $-0.2 \mathrm{~V}_{\mathrm{SCE}}$, followed by fast repassivation (Figure $7 \mathrm{a}, \mathrm{b}$ ). This suggests that the alloys are able to maintain the integrity of the air-formed passive film. When $10^{-2} \mathrm{M} \mathrm{S}_{2} \mathrm{O}_{3}{ }^{2-}$ was added to the $20 \% \mathrm{NaCl}$ solution, the $\mathrm{E}_{\mathrm{OCP}}$ values of DSS 2304 became more strongly negative from the beginning of the test, stabilizing at values close to $-0.45 \mathrm{~V}_{\mathrm{SCE}}$, in agreement with those measured during the SSRT in the same solution. This indicates that the air-formed passive film of DSS 2304 is no more compact and protective in this environment.
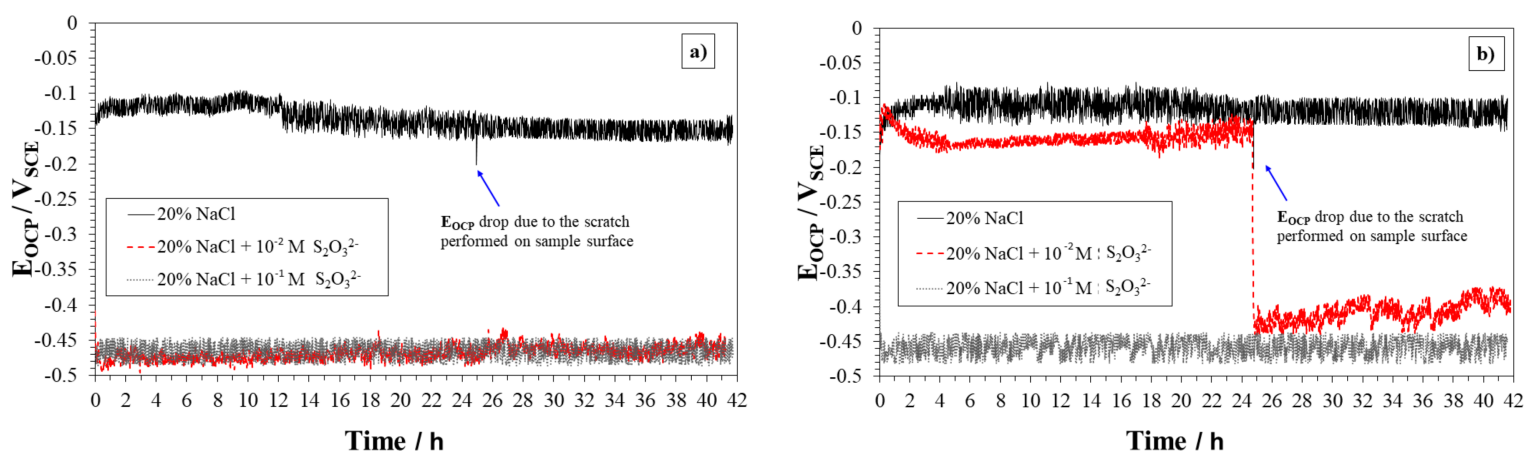

Figure 7. $\mathrm{E}_{\mathrm{OCP}}$-strain trends of DSS 2304 (a) and LDSS 2404 (b) during immersion in $20 \% \mathrm{NaCl}$ solution at $80^{\circ} \mathrm{C}$, in the absence and presence of $10^{-2}$ and $10^{-1} \mathrm{M} \mathrm{S}_{2} \mathrm{O}_{3}{ }^{2-}$. 
Conversely, $\mathrm{E}_{\mathrm{OCP}}$ of LDSS 2404 was about $-0.15 \mathrm{~V}_{\mathrm{SCE}}$ in this solution until a scratch was produced, which determined a significant drop of $\mathrm{E}_{\mathrm{OCP}}$ to values lower than $-0.40 \mathrm{~V}_{\mathrm{SCE}}$ (in agreement with trends observed during SSRT). These values were then maintained until the end of the test. This suggests that on this alloy the passive film is more stable than that formed on DSS 2304, but its repassivation at large flaws (scratches) is hindered by the likely conversion of $\mathrm{S}_{2} \mathrm{O}_{3}{ }^{2-}$ to sulphur and scarcely protective sulphides on the bare metal surface [27]. In the presence of $10^{-1} \mathrm{M} \mathrm{S}_{2} \mathrm{O}_{3}{ }^{2-}$, both alloys exhibited $\mathrm{E}_{\mathrm{OCP}}$ values in the $-0.45 \div-0.5 \mathrm{~V}_{\mathrm{SCE}}$ range, indicating active conditions. It is reasonable that the higher the $\mathrm{S}_{2} \mathrm{O}_{3}{ }^{2-}$ concentration, the higher the adsorbed sulphur coverage, which tends to inhibit the repassivation of film flaws and stimulate the corrosion attack, particularly on the less noble ferrite phase. Galvanic coupling with austenite may favour this selective attack [30,39-42].

Figure 8 presents the anodic polarization curves recorded in $20 \% \mathrm{NaCl}$ solution without or with $10^{-2} \mathrm{M} \mathrm{S}_{2} \mathrm{O}_{3}{ }^{2-}$ on both alloys, after $42 \mathrm{~h}$ of immersion. In the absence of $\mathrm{S}_{2} \mathrm{O}_{3}{ }^{2-}$, both alloys were passive and in spite of the scratch they exhibited an anodic curve with a wide passive-potential range spanning from $\mathrm{E}_{\mathrm{OCP}}$ up to a potential value where a rapid current increase was detected, due to pitting corrosion ( $\mathrm{E}_{\mathrm{pit}}$ ). LDSS 2404 showed a higher $\mathrm{E}_{\mathrm{pit}}$ and a lower passive-current density in comparison to DSS 2304, evidence of a superior passive-layer protectiveness in this environment. In a solution containing $10^{-2} \mathrm{M} \mathrm{S}_{2} \mathrm{O}_{3}{ }^{2-}$, DSS 2304 was not scratched, because it was in an active state since the beginning of the test, with $\mathrm{E}_{\mathrm{OCP}}$ values around $-0.45 \mathrm{~V}_{\mathrm{SCE}}$. Its final anodic polarization curve shows a relatively low anodic slope, confirming that in this environment the passive film is markedly damaged. Conversely, LDSS 2404 which exhibited a noble $\mathrm{E}_{\mathrm{OCP}}$ during the immersion and underwent a $250 \mathrm{mV}$ decrease after scratching, displayed a polarization curve typical of pseudopassive corrosion behaviour, evidenced by quite a high anodic slope of the polarization curve and relatively high passive currents (about $3 \times 10^{-5} \mathrm{~A} \mathrm{~cm}^{-2}$ ). These are likely connected to the presence of the artificial defect in the oxide film. The steep anodic slope testifies to the high intrinsic corrosion resistance of the alloy in spite of the defect. In the presence of $10^{-1} \mathrm{M} \mathrm{S}_{2} \mathrm{O}_{3}{ }^{2-}$ (curves not shown), both alloys resulted active just after the immersion, due to the significant environmental aggressiveness, and polarization curves similar to that exhibited with DSS 2304 in $10^{-2} \mathrm{M} \mathrm{S}_{2} \mathrm{O}_{3}{ }^{2-}$ were obtained.

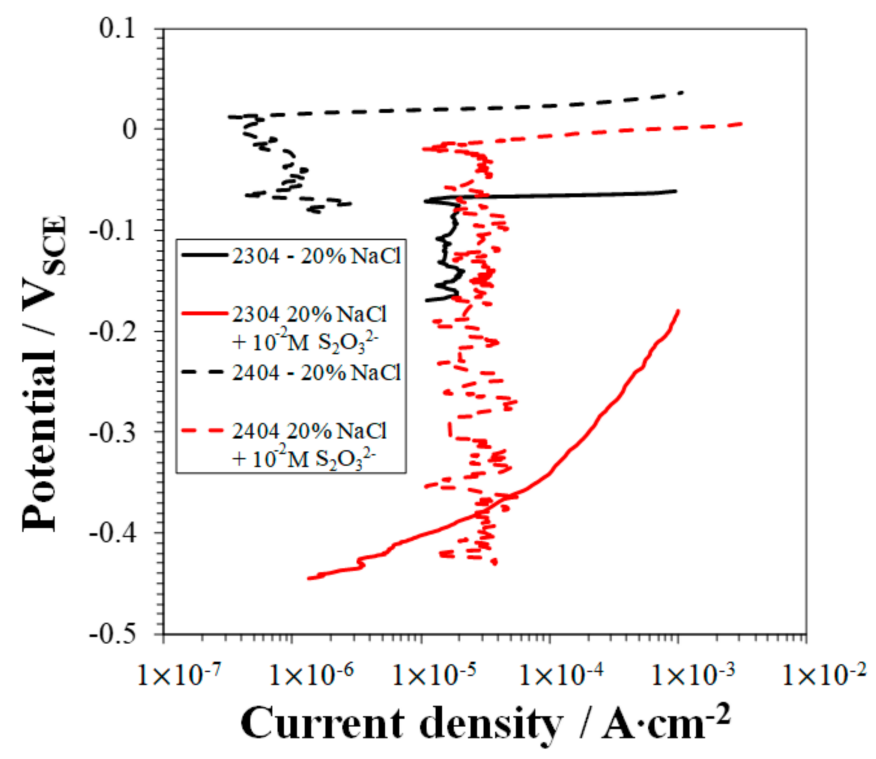

Figure 8. Polarization curves recorded on DSS 2304 and LDSS 2404 after $42 \mathrm{~h}$ immersion in $20 \% \mathrm{NaCl}$ solution at $80^{\circ} \mathrm{C}$, in the absence and in the presence of $10^{-2} \mathrm{M} \mathrm{S}_{2} \mathrm{O}_{3}{ }^{2-}$.

These tests suggest that in $20 \% \mathrm{NaCl}$ solution the alloys are scarcely affected by the presence of flaws in the passive film, such as those artificially produced or those caused by tensile straining during 
SSRT, because fast spontaneous healing of the passive film occurs. This may hinder both SCC and general corrosion attack of the alloys in this environment.

$\mathrm{S}_{2} \mathrm{O}_{3}{ }^{2-}$ addition affects the alloy oxide stability of DSS 2304 under dynamic (Figure 6) and also under static (Figures 7 and 8) conditions, at both $\mathrm{S}_{2} \mathrm{O}_{3}{ }^{2-}$ concentrations. On this alloy, active $\mathrm{E}_{\mathrm{OCP}}$ values are detected in conjunction with selective ferrite corrosion (static and SSRT) and SCC attack (SSRT at $10^{-2} \mathrm{MS}_{2} \mathrm{O}_{3}{ }^{2-}$ concentrations). $\mathrm{S}_{2} \mathrm{O}_{3}{ }^{2-}$ is also aggressive towards LDSS 2404 (Figures 6 and 7). In $10^{-2} \mathrm{M} \mathrm{S}_{2} \mathrm{O}_{3}{ }^{2-}$, the alloy is passive under static conditions, but undergoes a $250 \mathrm{mV}$ shift of $\mathrm{E}_{\mathrm{OCP}}$ towards the negative direction if the film is damaged by tensile strain (Figure 6) or by scratching (Figures 6-8), due to the onset of ferrite corrosion. The histogram of Figure 9 compares the R index values calculated for DSS 2304 and LDSS 2404 to those obtained for LDSS 2101 [18]. An R value of 0.79 indicates a slight susceptibility to SCC of DSS 2304 in $20 \% \mathrm{NaCl}$ solution at $80^{\circ} \mathrm{C}$ in the presence of the lowest tested $\mathrm{S}_{2} \mathrm{O}_{3}{ }^{2-}$ concentration $\left(10^{-2} \mathrm{M}\right)$. The same behaviour was observed for LDSS 2101 [18]. No SCC susceptibility was detected for LDSS 2404.

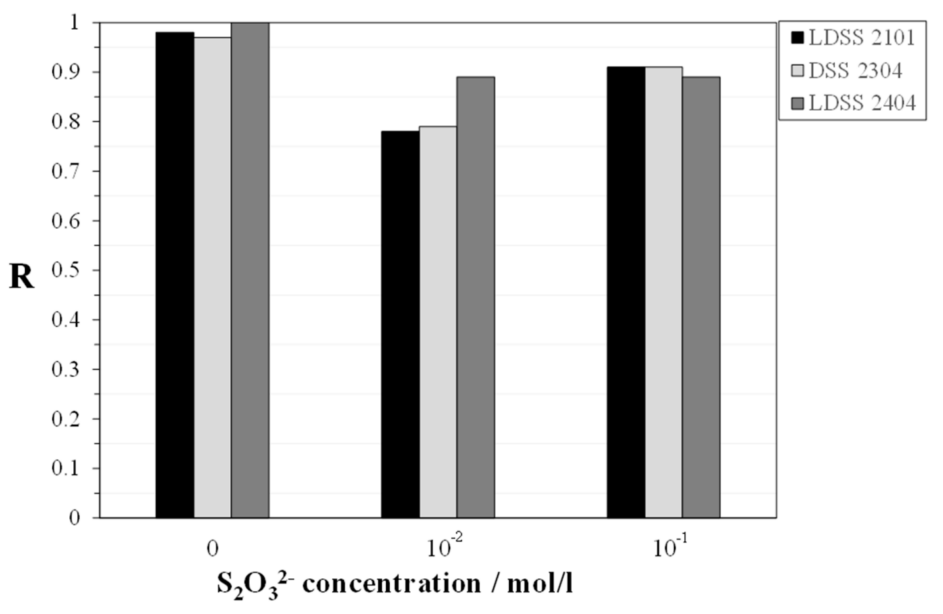

Figure 9. $\mathrm{R}$ index of the studied LDSS in $20 \% \mathrm{NaCl}$ solution at $80^{\circ} \mathrm{C}$, in the absence and in the presence of $10^{-2}$ and $10^{-1} \mathrm{MS}_{2} \mathrm{O}_{3}{ }^{2-}$.

The different behaviour of the studied alloys can be predicted from their PREN values (Table 1) and is in strong correlation with their Mo content. In particular, LDSS 2404 with its Mo percentage about 5 times higher than that of DSS 2304 and LDSS 2101 ensures the best corrosion behaviour. Literature results $[43,44]$ show that alloyed Mo reduces SCC and pitting-corrosion susceptibility of $\mathrm{Ni}-\mathrm{Cr}-\mathrm{Mo}-\mathrm{Fe}$ alloy in a $\mathrm{H}_{2} \mathrm{~S}_{-} \mathrm{Cl}^{-}$environment, due to the formation of stable molybdenum sulphide in the outer layer of the surface film which, being cation-selective, protects the inner chromium oxide layer from $\mathrm{Cl}^{-}$attack. Moreover, Mo containing SS and DSS grades also exhibit a higher pitting-corrosion resistance in $\mathrm{Cl}^{-} / \mathrm{S}_{2} \mathrm{O}_{3}{ }^{2-}$ environments in comparison to low-Mo grades [45].

\subsection{SSRT Results in NACE TM-0177 Solution at $25^{\circ} \mathrm{C}$ without/with $\mathrm{S}_{2} \mathrm{O}_{3}{ }^{2-}$}

Figure 10 depicts the stress-strain curves of DSS 2304 (a) and LDSS 2404 (b) acquired during SSRT performed in air at $25^{\circ} \mathrm{C}$ and in NACE TM- 0177 solution at $25^{\circ} \mathrm{C}$, in the absence and in the presence of $10^{-3}$ and $10^{-2} \mathrm{M} \mathrm{S}_{2} \mathrm{O}_{3}{ }^{2-}$.

In the absence of $\mathrm{S}_{2} \mathrm{O}_{3}{ }^{2-}$, both alloys present stress-strain curves quite similar to those recorded in air at the same temperature, suggesting that they do not suffer SCC in this environment. At the lowest tested $\mathrm{S}_{2} \mathrm{O}_{3}{ }^{2-}$ concentration $\left(10^{-3} \mathrm{M}\right)$, DSS 2304 showed a stress-strain curve similar to that recorded in air (Figure 10) and a ductile-type fracture, without secondary cracks. At the highest tested $\mathrm{S}_{2} \mathrm{O}_{3}{ }^{2-}$ concentration $\left(10^{-2} \mathrm{M}\right)$, this alloy underwent a significant $\varepsilon_{\mathrm{f}} \%$ reduction and several secondary cracks, likely developed from pits [30] (Figure 11), were detected in the gauge length portion of tensile specimens, characterized by a brittle fracture type. These secondary cracks propagated within the $\alpha$ 
phase and followed both $\gamma / \gamma$ and $\alpha / \gamma$ grain boundaries, but an intense selective attack of the ferrite phase was not observed. Like DSS 2304, LDSS 2101 [18] also exhibited decreasing $\varepsilon_{\mathrm{f}} \%$ at increasing $\mathrm{S}_{2} \mathrm{O}_{3}{ }^{2-}$ content in the NACE TM-0177 solution.
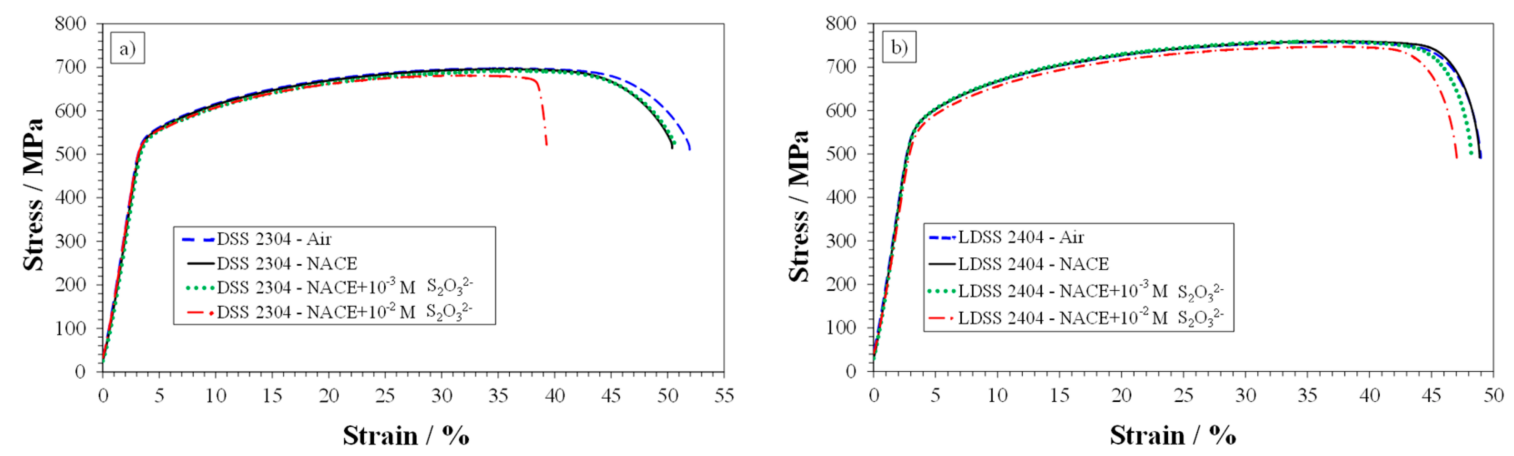

Figure 10. Stress-strain curves obtained during SSRT performed in air at $25^{\circ} \mathrm{C}$ and in NACE TM-0177 solution at $25{ }^{\circ} \mathrm{C}$ and $\mathrm{pH} 2.7$, in the absence and in the presence of $10^{-3}$ or $10^{-2} \mathrm{M} \mathrm{S}_{2} \mathrm{O}_{3}{ }^{2-}$ on DSS 2304 (a) and on LDSS 2404 (b).
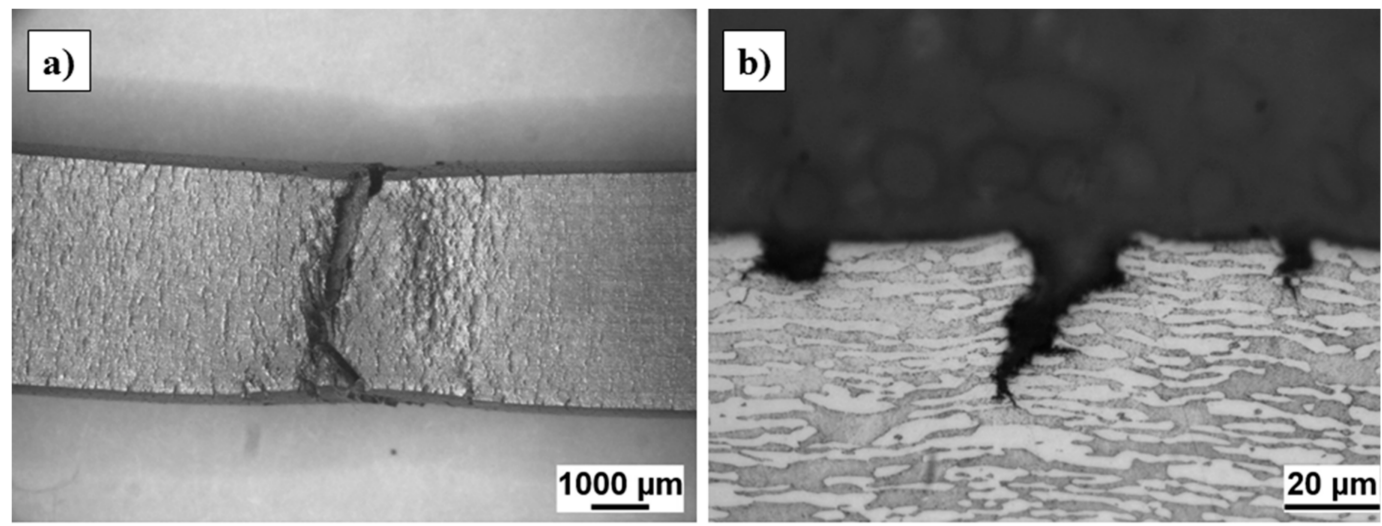

Figure 11. Macrograph (a) and micrograph (b) of the long transversal section of DSS 2304 sample after SSRT in NACE TM-0177 solution at $25^{\circ} \mathrm{C}$ and $\mathrm{pH} 2.7$, in the presence of $10^{-2} \mathrm{M} \mathrm{S}_{2} \mathrm{O}_{3}{ }^{2-}$.

By contrast, LDSS 2404 maintained high ductility, comparable to that obtained in air at $25^{\circ} \mathrm{C}$, also in the presence of $\mathrm{S}_{2} \mathrm{O}_{3}{ }^{2-}$ at both tested concentrations, as shown in Figure 10. The ductile-type fracture obtained on this alloy in air and in the presence of $10^{-2} \mathrm{M} \mathrm{S}_{2} \mathrm{O}_{3}{ }^{2-}$ is shown in Figure 12.
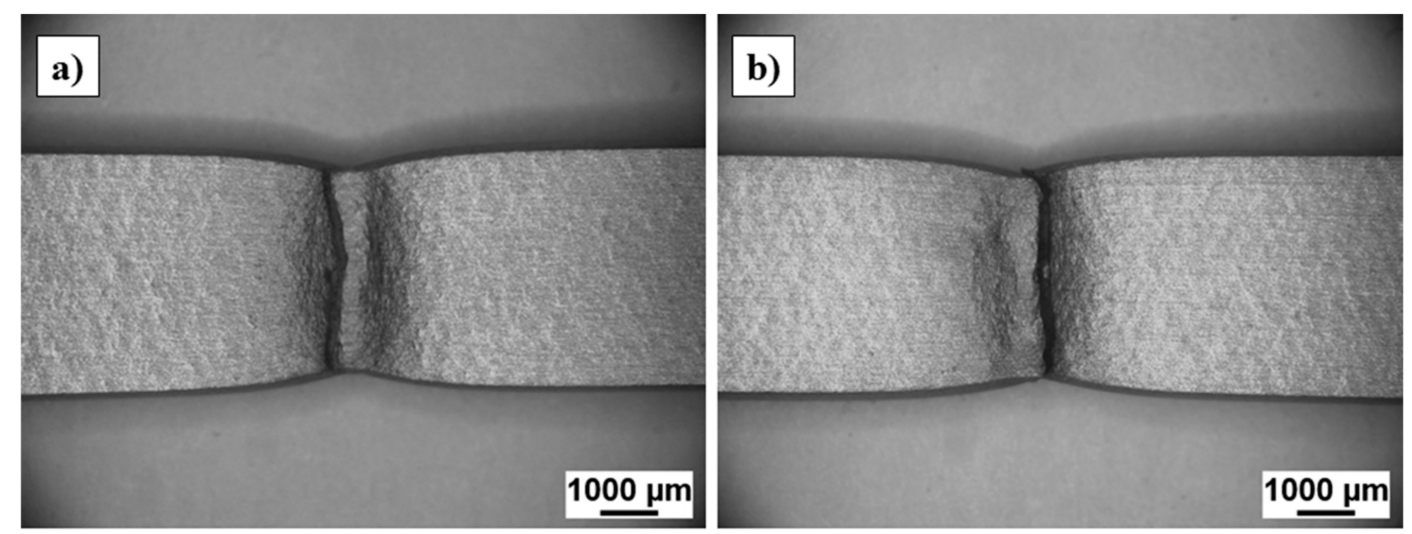

Figure 12. Macrograph of LDSS 2404 sample after SSRT in air at $25^{\circ} \mathrm{C}$ (a) and in NACE TM-0177 solution at $25^{\circ} \mathrm{C}$ and $\mathrm{pH} 2.7$, in the presence of $10^{-2} \mathrm{M} \mathrm{S}_{2} \mathrm{O}_{3}{ }^{2-}$ (b). 
The $\mathrm{E}_{\mathrm{OCP}}$-strain curves for DSS 2304 and LDSS 2404 during SSRT in NACE TM-0177 solution containing or not containing $\mathrm{S}_{2} \mathrm{O}_{3}{ }^{2-}$ are presented in Figure 13. Without $\mathrm{S}_{2} \mathrm{O}_{3}{ }^{2-}$, the $\mathrm{E}_{\mathrm{OCP}}$ of DSS 2304 set around $-0.3 \mathrm{~V}_{\mathrm{SCE}}$ and that of LDSS 2404 to slightly more positive values (about $-0.24 \mathrm{~V}_{\mathrm{SCE}}$, towards the end of the test), at which a stable passive layer forms on both alloys [28]. When $\mathrm{S}_{2} \mathrm{O}_{3}{ }^{2-}$ was added, all $\mathrm{E}_{\mathrm{OCP}}$ values shifted towards more positive values with the exception of that recorded on DSS 2304, in the presence of the highest $\mathrm{S}_{2} \mathrm{O}_{3}{ }^{2-}$ concentration $\left(10^{-2} \mathrm{M}\right)$. In this case, the $\mathrm{E}_{\mathrm{OCP}}$ values decreased down to $-0.5 \mathrm{~V}_{\mathrm{SCE}}$, likely due to the synergistic effect of $\mathrm{Cl}^{-}$and $\mathrm{S}_{2} \mathrm{O}_{3}{ }^{2-}$ [24], favouring the development of pits from which a crack propagated. Under these acidic $\mathrm{pH}$ conditions, such a negative potential value permits the reduction of $\mathrm{S}_{2} \mathrm{O}_{3}{ }^{2-}$ to $\mathrm{S}$ and $\mathrm{H}_{2} \mathrm{~S}[22,23]$ on the crack's walls and favours $\mathrm{H}$ penetration and embrittlement of the alloy, inducing S-SCC. In this environment, a concentration of $10^{-4} \mathrm{M} \mathrm{S}_{2} \mathrm{O}_{3}{ }^{2-}$ was sufficient to induce S-SCC on LDSS 2101 and SCC susceptibility increased at increasing $\mathrm{S}_{2} \mathrm{O}_{3}{ }^{2-}$ concentration, because more $\mathrm{H}_{2} \mathrm{~S}$ formed on the active sites of the sample surface [18].
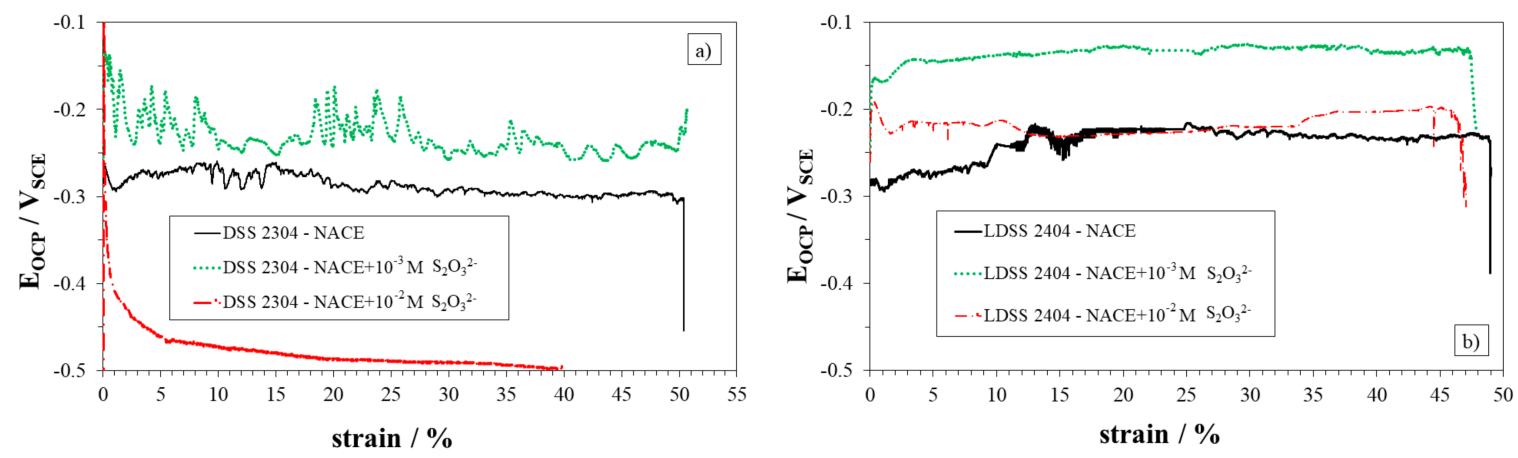

Figure 13. $\mathrm{E}_{\mathrm{OCP}}$-strain trends of DSS 2304 (a) and LDSS 2404 (b) during SSRT in NACE TM-0177 solution at $25^{\circ} \mathrm{C}$ and $\mathrm{pH} 2.7$, in the absence and presence of $10^{-3}$ and $10^{-2} \mathrm{M} \mathrm{S}_{2} \mathrm{O}_{3}{ }^{2-}$.

Actually, at this low $\mathrm{pH}$, the nobler $\mathrm{E}_{\mathrm{OCP}}$ values of $-0.14 /-0.3 \mathrm{~V}_{\mathrm{SCE}}$ achieved by LDSS 2404 in the presence of $\mathrm{S}_{2} \mathrm{O}_{3}{ }^{2-}$ and by DSS 2304 in diluted $\mathrm{S}_{2} \mathrm{O}_{3}{ }^{2-}$ solutions are also compatible with the reduction of $\mathrm{S}_{2} \mathrm{O}_{3}{ }^{2-}$ to adsorbed sulphur and then to $\mathrm{H}_{2} \mathrm{~S}[26,28]$. However, it is likely that, at these nobler $\mathrm{E}_{\mathrm{OCP}}$ values, only small amounts of $\mathrm{S}$ and $\mathrm{H}_{2} \mathrm{~S}$ can be produced that may be insufficient to stabilize metastable pits from which SCC develops [21].

During static immersions in NACE TM-0177 solution containing $10^{-2} \mathrm{M} \mathrm{S}_{2} \mathrm{O}_{3}{ }^{2-}, \mathrm{E}_{\mathrm{OCP}}$-time trends (Figure 14) were recorded for $42 \mathrm{~h}$ on DSS 2304 and LDSS 2404 electrodes.

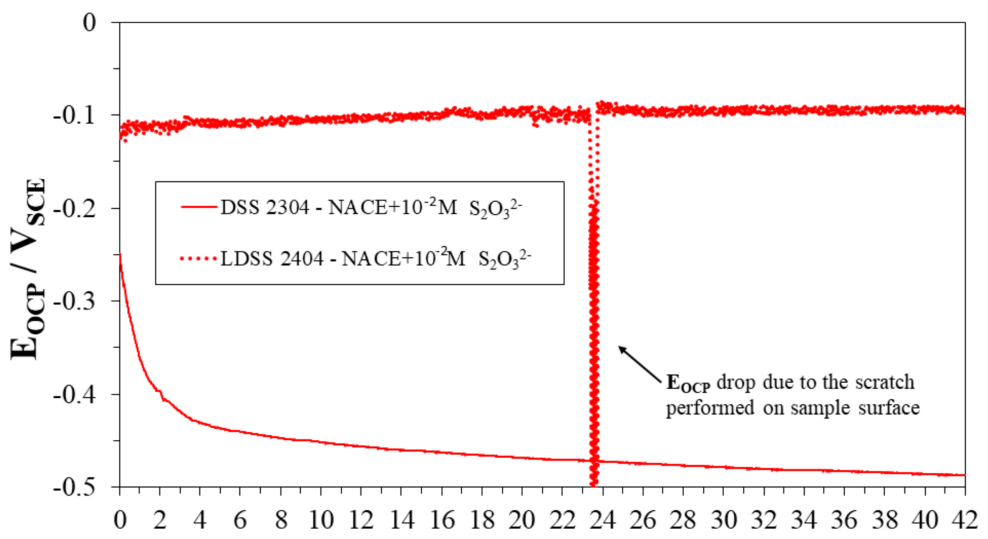

Time / h

Figure 14. $\mathrm{E}_{\mathrm{OCP}}$-time trends of DSS 2304 and LDSS 2404 during immersion in NACE TM-0177 solution at $25^{\circ} \mathrm{C}$ and $\mathrm{pH} 2.7$, in the presence of $10^{-2} \mathrm{M} \mathrm{S}_{2} \mathrm{O}_{3}{ }^{2-}$. 
In spite of the absence of applied stress, the results were similar to those obtained during SSRT and shown in Figure 13. In fact, also under static conditions, the E quickly in the negative direction, from an initial value of $-0.25 \mathrm{~V}_{\mathrm{SCE}}$ down to $-0.5 \mathrm{~V}_{\mathrm{SCE}}$. In this test, the electrode was not scratched. Conversely, LDSS 2404 exhibited stable noble $\mathrm{E}_{\mathrm{OCP}}$ values close to $-0.1 \mathrm{~V}_{\mathrm{SCE}}$, indicating the presence of passive conditions, capable of recovering quickly after scratching (at about $24 \mathrm{~h}$ of immersion, Figure 14). In Figure 15, the final anodic polarization curves are shown. They confirm that DSS 2304 is under active conditions, while LDSS 2404 exhibit a passive behaviour, with passive currents around $10^{-5} \mathrm{~A} \mathrm{~cm}^{-2}$ or lower, in spite of the presence of the scratch.

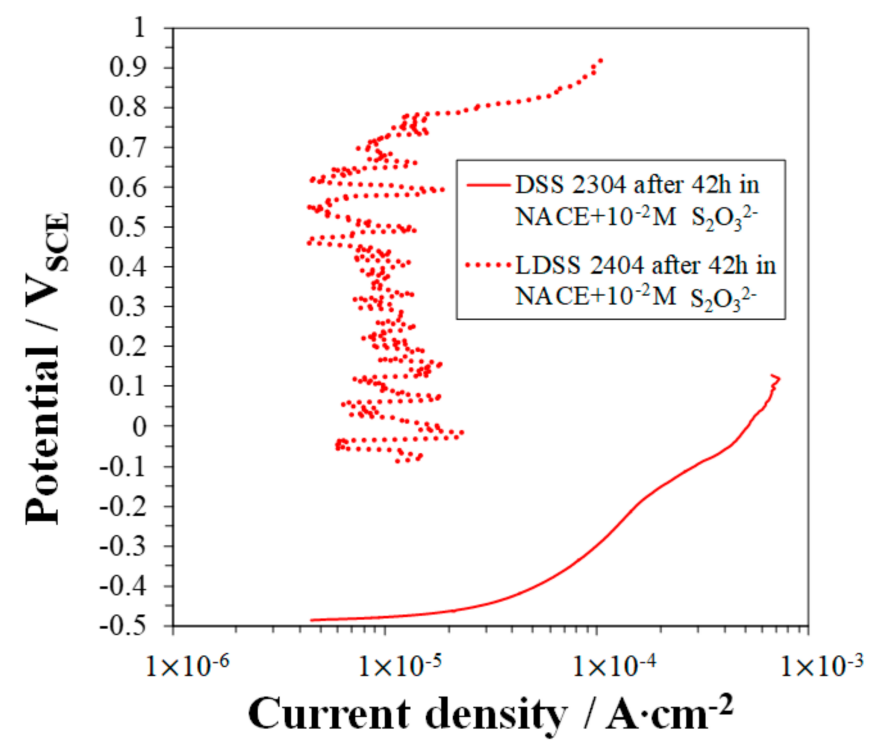

Figure 15. Polarization curves recorded on DSS 2304 and LDSS 2404 after $42 \mathrm{~h}$ immersion in NACE TM-0177 solution at $25^{\circ} \mathrm{C}$ and $\mathrm{pH} 2.7$, in the presence of $10^{-2} \mathrm{M} \mathrm{S}_{2} \mathrm{O}_{3}{ }^{2-}$.

The histogram of Figure 16 compares the R index values calculated for DSS 2304 and LDSS 2404, to those obtained for LDSS 2101 [18] in NACE TM-0177 solution at $25^{\circ} \mathrm{C}$, in the absence and in the presence of $\mathrm{S}_{2} \mathrm{O}_{3}{ }^{2-}$. DSS 2404 was never susceptible to SCC independent of $\mathrm{S}_{2} \mathrm{O}_{3}{ }^{2-}$ concentration, as $\mathrm{R}$ values were always very close to 1 . By contrast, DSS 2304 (and LDSS 2101) showed an increase in SCC susceptibility at increasing $\mathrm{S}_{2} \mathrm{O}_{3}{ }^{2-}$ content. A $10^{-2} \mathrm{M}$ concentration of $\mathrm{S}_{2} \mathrm{O}_{3}{ }^{2-}$ was necessary to induce SCC failure on DSS 2304, while a $10^{-4} \mathrm{M} \mathrm{S}_{2} \mathrm{O}_{3}{ }^{2-}$ addition was sufficient for LDSS 2101 [18]. Moreover, the latter alloy was significantly more susceptible to SCC in comparison to DSS 2304 at concentrations of $10^{-3}$ and $10^{-2} \mathrm{M}$.

In NACE TM-0177 solution, LDSS 2101 results significantly more susceptible to SCC in comparison to DSS 2304 (Figure 16), and a $\mathrm{S}_{2} \mathrm{O}_{3}{ }^{2-}$ concentration of $10^{-4} \mathrm{M}$ is high enough to induce a slight SCC susceptibility on this alloy [18]. This behaviour may be connected to the presence of a relevant content of Mn, which has a detrimental effect on pitting-corrosion resistance [14,46]. A PREN formula different from that reported in Table 1 has been proposed [47,48], in order to rate alloys regarding their pitting-corrosion resistance and including the influence of Mn content. According to this formula $\left(\mathrm{PREN}_{\mathrm{Mn}}=\% \mathrm{Cr}+3.3 \% \mathrm{Mo}+30 \% \mathrm{~N}-1 \% \mathrm{Mn}\right)$, LDSS 2101 is less resistant $\left(\mathrm{PREN}_{\mathrm{Mn}}=24\right)$, than DSS $2304\left(\left(\mathrm{PREN}_{\mathrm{Mn}}=27\right)\right.$ and LDSS $2404\left(\mathrm{PREN}_{\mathrm{Mn}}=34\right)$. Considering that in $\mathrm{Cl}^{-} / \mathrm{H}_{2} \mathrm{~S}$ solutions SCC cracks are reputed to develop from pits [30], a high Mn content may contribute to affect pitting and thus SCC resistance in SSRT. In LDSS 2404, the detrimental effect of Mn is counterbalanced by the high content of Mo, so ensuring high SCC resistance [31,46].

In $\mathrm{S}_{2} \mathrm{O}_{3}{ }^{2}$ containing $20 \% \mathrm{NaCl}$ solution at $80^{\circ} \mathrm{C}$, the detrimental influence of $\mathrm{Mn}$ is likely less relevant to explain differences in SCC behaviour of the studied alloys, because pitting is not detected. Instead, the selective corrosion of the ferrite phase appears competitive with SCC. Therefore, LDSS 
2101 and DSS 2304 show almost the same behaviour, while LDSS 2404 maintains high performance because of its high Mo content.

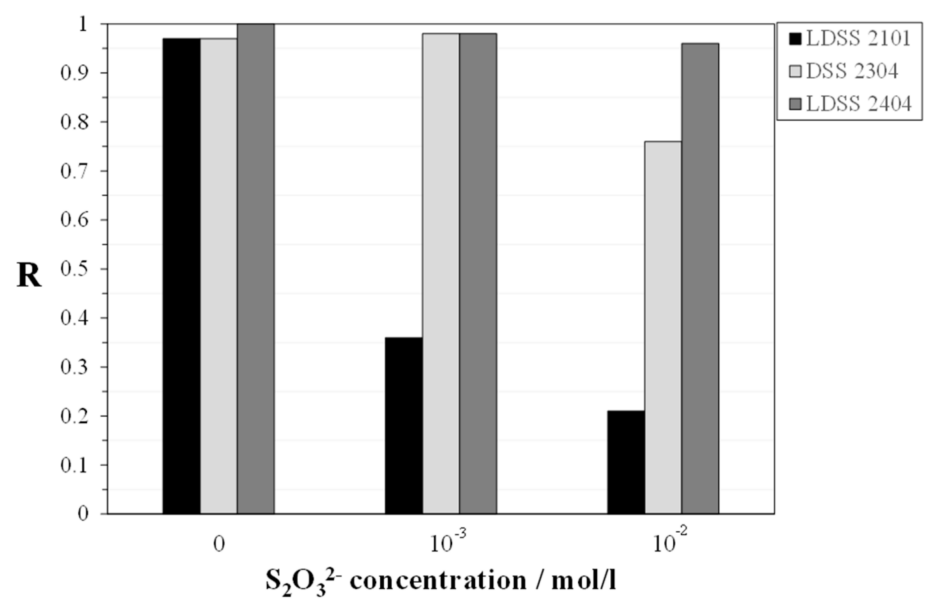

Figure 16. R index of the studied LDSS in NACE TM- 0177 solution at $25^{\circ} \mathrm{C}$ and $\mathrm{pH} 2.7$, in the absence and presence of $10^{-3}$ and $10^{-2} \mathrm{M} \mathrm{S}_{2} \mathrm{O}_{3}{ }^{2-}$.

\section{Conclusions}

1. During SSRT, the studied LDSS grades did not exhibit SCC in $20 \% \mathrm{NaCl}$ solution at $80{ }^{\circ} \mathrm{C}$ and in NACE TM-0177 solution at $25^{\circ} \mathrm{C}$ and $\mathrm{pH} 2.7$, in the absence of $\mathrm{S}_{2} \mathrm{O}_{3}{ }^{2-}$.

2. The addition of $\mathrm{S}_{2} \mathrm{O}_{3}{ }^{2-}$ in $20 \% \mathrm{NaCl}$ solution at $80{ }^{\circ} \mathrm{C}$ produced selective corrosion of the ferrite phase in all alloys.

3. In $20 \% \mathrm{NaCl}$ solution containing $\mathrm{S}_{2} \mathrm{O}_{3}{ }^{2-}$, a selective corrosion attack on the ferrite phase was in competition with SCC. The latter corrosion form prevailed at the lowest tested $\mathrm{S}_{2} \mathrm{O}_{3}{ }^{2-}$ concentration $\left(10^{-2} \mathrm{M}\right)$ on both DSS 2304 and LDSS 2101 . At $10^{-1} \mathrm{M}$, ferrite dissolution produced crack blunting and SCC was not observed. LDSS 2404 was immune to SCC at both $\mathrm{S}_{2} \mathrm{O}_{3}{ }^{2-}$ concentrations.

4. In NACE TM-0177 solution at $25^{\circ} \mathrm{C}$ and $\mathrm{pH} 2.7$ containing $\mathrm{S}_{2} \mathrm{O}_{3}{ }^{2-}$, no selective ferrite corrosion was observed. On LDSS 2101 and DSS 2304, the higher the $\mathrm{S}_{2} \mathrm{O}_{3}{ }^{2-}$ concentration, the stronger the alloy susceptibility to S-SCC. LDSS 2404 was immune to SCC.

5. The SCC behaviour of the three alloys studied strongly depended on their composition. In particular, the presence of a significant amount of Mo increased the SCC resistance of LDSS 2404 in both environments, while the high Mn content in LDSS 2101 negatively affected the alloy SCC resistance in NACE TM-0177 solution containing $\mathrm{S}_{2} \mathrm{O}_{3}{ }^{2-}$, where pits play an important role as crack initiators.

Acknowledgments: This work was developed within the framework of the 2007-2013 Emilia-Romagna Regional Operational Programme of the European Regional Development Fund (ERDF ROP)-priority 1 Industrial research and technological transfer: "Creation of Technopoles for industrial research and technology transfer". The material was kindly supplied by Outokumpu S.p.A.

Author Contributions: Fabrizio Zucchi and Cecilia Monticelli conceived and designed the experiments; Federica Zanotto and Vincenzo Grassi performed the experiments; Federica Zanotto and Andrea Balbo analyzed the data; Federica Zanotto, Cecilia Monticelli and Andrea Balbo wrote the paper.

Conflicts of Interest: The authors declare no conflict of interest. 


\section{References}

1. Charles, J.; Chemelle, P. The history of duplex developments, nowadays DSS properties and duplex market future trends. In Proceedings of the 8th Duplex Stainless Steels conference, Beaune, France, 13-15 October 2010.

2. Bhattacharya, A.; Singh, P.M. Role of microstructure on the corrosion susceptibility of UNS S32101 duplex stainless steel. Corrosion 2008, 64, 532-540. [CrossRef]

3. Jiang, Y.; Tan, H.; Wang, Z.; Hong, J.; Jiang, L.; Li, J. Influence of Creq/Nieq on pitting corrosion resistance and mechanical properties of UNS S32304 duplex stainless steel welded joints. Corros. Sci. 2013, 70, 252-259. [CrossRef]

4. Johansson, E.; Pettersson, R. Lean Duplex Stainless Steel within the Oil and Gas Industry. In European Corrosion Congress; Gubkin Russian State University of Oil and Gas: Moscow, Russia, 2010; Volume 4, pp. 2869-2878.

5. Kudo, T.; Tsuge, H.; Moroishi, T. Stress corrosion cracking resistance of 22 duplex stainless steel in simulated sour environments. Corrosion 1989, 45, 831-838. [CrossRef]

6. El-Yazgi, A.A.; Hardie, D. Stress corrosion cracking of duplex and super duplex stainless steels in sour environments. Corros. Sci. 1998, 40, 909-930. [CrossRef]

7. De Moraes, F.D.; Bastian, F.L.; Ponciano, J.A. Influence of dynamic straining on hydrogen embrittlement of UNS-G41300 and UNS-S31803 steels in a low $\mathrm{H}_{2} \mathrm{~S}$ concentration environment. Corros. Sci. 2005, 47, 1325-1335. [CrossRef]

8. Sozanska, M.; Kłyk-Spyra, K. Investigation of hydrogen induced cracking in 2205 duplex stainless steel in wet $\mathrm{H}_{2} \mathrm{~S}$ environments after isothermal treatment at 675,750 and $900{ }^{\circ} \mathrm{C}$. Mater. Charact. 2006, 56, 399-404. [CrossRef]

9. Liu, Z.Y.; Dong, C.F.; Li, X.G.; Zhi, Q.; Cheng, Y.F. Stress corrosion cracking of 2205 duplex stainless steel in $\mathrm{H}_{2} \mathrm{~S}-\mathrm{CO}_{2}$ environment. J. Mater. Sci. 2009, 44, 4228-4234. [CrossRef]

10. Mukai, S.; Okamoto, H.; Kudo, T.; Ikeda, A. Corrosion behaviour of 25 Pct Cr duplex stainless steel in $\mathrm{CO}_{2}-\mathrm{H}_{2} \mathrm{~S}-\mathrm{Cl}^{-}$environments. J. Mater. Energy Syst. 1983, 5, 59-66. [CrossRef]

11. Rhodes, P.R.; Welch, G.A.; Abrego, L. Stress corrosion cracking susceptibility of duplex stainless steels in sour gas environments. J. Mater. Energy Syst. 1983, 5, 3-18. [CrossRef]

12. Schofield, M.J.; Bradshaw, R.; Cottis, R.A. Stress corrosion cracking of duplex stainless steel weldments in sour conditions. Mater. Perform. 1996, 35, 65-70.

13. Cao, L.; Anderko, A.; Gui, F.; Sridhar, N. Localized corrosion of corrosion resistant alloys in $\mathrm{H}_{2} \mathrm{~S}$-Containing environments. Corrosion 2016, 72, 636-654. [CrossRef]

14. Ruel, F.; Saedlou, S.; Mendibide, C.; Manchet, S.L.; Wolski, K. Effect of the substitution of Ni by N and Mn in Lean Duplex Stainless steels on Stress corrosion Cracking assisted by $\mathrm{H}_{2} \mathrm{~S}$. In NACE-International Corrosion Conference Series; National Association of Corrosion Engineers: Houston, TX, USA, 2017; pp. 3376-3387.

15. Olsson, J.; Snis, M. Duplex-A new generation of stainless steels for desalination plants. Desalination 2007, 205, 104-113. [CrossRef]

16. Snis, M.; Olsson, J. Reduce costs for storage and distribution of desalted water-Use duplex stainless steel. Desalination 2008, 223, 476-486. [CrossRef]

17. Yang, Y.; Tan, H.; Zhang, Z.; Wang, Z.; Jiang, Y.; Jiang, L.; Li, J. Effect of annealing temperature on the pitting corrosion behavior of UNS S82441 duplex stainless steel. Corrosion 2013, 69, 167-173. [CrossRef]

18. Zanotto, F.; Grassi, V.; Balbo, A.; Monticelli, C.; Zucchi, F. Stress corrosion cracking of LDX 2101®duplex stainless steel in chloride solutions in the presence of thiosulphate. Corros. Sci. 2014, 80, 205-212. [CrossRef]

19. Zanotto, F.; Grassi, V.; Merlin, M.; Balbo, A.; Zucchi, F. Effect of brief heat treatments performed between 650 and $850{ }^{\circ} \mathrm{C}$ on corrosion behaviour of a lean duplex stainless steel. Corros. Sci. 2015, 94, 38-47. [CrossRef]

20. Zanotto, F.; Grassi, V.; Zucchi, F.; Merlin, M.; Balbo, A.; Monticelli, C. Effect of sensitization on stress corrosion cracking behaviour of LDX 2101 stainless steel. La Metallurgia Italiana 2016, 108, 24-33.

21. Zanotto, F.; Grassi, V.; Balbo, A.; Monticelli, C.; Melandri, C.; Zucchi, F. Effect of brief thermal aging on stress corrosion cracking susceptibility of LDSS 2101 in the presence of chloride and thiosulphate ions. Corros. Sci. 2018, 130, 22-30. [CrossRef] 
22. Tsujikawa, S.; Miyasaka, A.; Ueda, M.; Ando, S.; Shibata, T.; Haruna, T.; Katahira, M.; Yamane, Y.; Aoki, T.; Yamada, T. Alternative for evaluating sour gas resistance of low-alloy steels and corrosion-resistant alloys. Corrosion 1993, 49, 409-419. [CrossRef]

23. Tsujikawa, J. An alternative test method for evaluating the sour gas resistance of low-alloy steels and CRAs. In Proc. Corrosion '92; NACE International: Huston, TX, USA, 1992; p. 45.

24. Choudhary, L.; Macdonald, D.D.; Alfantazi, A. Role of thiosulfate in the corrosion of steels: A review. Corrosion 2015, 71, 1147-1168. [CrossRef]

25. Kappes, M.; Frankel, G.S.; Sridhar, N.; Carranza, R.M. Reaction Paths of Thiosulphate during Corrosion of Carbon Steel in Acidified Brines. J. Electrochem. Soc. 2012, 159, C195-C204. [CrossRef]

26. Marcus, P.; Protopopoff, E. Thermodynamics of thiosulphate reduction on surfaces of iron, nickel and chromium in water at 25 and $300{ }^{\circ}$ C. Corros. Sci. 1997, 39, 1741-1752. [CrossRef]

27. Duret-Thual, C.; Costa, D.; Yang, W.P.; Marcus, P. The role of thiosulphates in the pitting corrosion of Fe-17Cr alloys in neutral chloride solution: electrochemical and XPS study. Corros. Sci. 1997, 39, 913-933. [CrossRef]

28. Marcus, P.; Oudar, J. Corrosion Mechanism in Theory and Practice, 2nd ed.; Marcel Dekker Inc.: New York, NY, USA, 1995; pp. 240-248. ISBN 0-8247-0666-8.

29. Newman, R.C.; Isaacs, H.S.; Alman, B. Effect of sulfur compounds on the pitting behavior of type 304 stainless steel in near-neutral chloride solutions. Corrosion 1982, 38, 261-264. [CrossRef]

30. Marcus, P.; Oudar, J. Corrosion Mechanism in Theory and Practice, 2nd ed.; Marcel Dekker Inc.: New York, NY, USA, 1995; pp. 342-346. ISBN 0-8247-0666-8.

31. Canderyd, C.; Pettersson, R. UNS S82441-A new duplex stainless steel grade for the process industries. In NACE-International Corrosion Conference Series; National Association of Corrosion Engineers: Houston, TX, USA, 2012; Volume 5, pp. 4081-4090.

32. Lo, K.H.; Shek, C.H.; Lai, J.K.L. Recent developments in stainless steels. Mater. Sci. Eng. R 2009, 65, 39-104. [CrossRef]

33. Garfias-Mesias, L.F.; Sykes, J.M.; Tuck, C.D.S. The effect of phase compositions on the pitting corrosion of $25 \mathrm{Cr}$ duplex stainless steel in chloride solutions. Corros. Sci. 1996, 38, 1319-1330. [CrossRef]

34. Jones, R.H.; Ricker, R.E. Stress-Corrosion Cracking. In Corrosion, Metals Handbook, 9th ed.; ASM International: Geauga County, OH, USA, 1988; Volume 13, p. 262.

35. NACE standard TM-0177-90 Standard Test Method Laboratory Testing of Metals for Resistance to Sulfide Stress Cracking in $\mathrm{H}_{2} \mathrm{~S}$ Environments; NACE International: Huston, TX, USA, 1990.

36. Zucchi, F.; Trabanelli, G.; Grassi, V. Stress corrosion cracking of $13 \%$ Cr martensitic steels in sodium chloride solutions in the presence of thiosulphate. Mater. Corros. 2000, 51, 207-212. [CrossRef]

37. "Duplex, Lean Duplex and Super Duplex Stainless Steels-Twice as Strong as Austenitics". Available online: http:/ / www.outokumpu.com/en/products-properties/more-stainless/stainless-steeltypes/duplex/Pages/default.aspx (accessed on 24 March 2018).

38. Ezuber, H.M. Influence of temperature and thiosulfate on the corrosion behaviour of steel in chloride solutions saturated in $\mathrm{CO}_{2}$. Mater. Des. 2009, 30, 3420-3427. [CrossRef]

39. Bellezze, T.; Giuliani, G.; Viceré, A.; Roventi, G. Study of stainless steels corrosion in a strong acid mixture. Part 2: anodic selective dissolution, weight loss and electrochemical impedance spectroscopy tests. Corros. Sci. 2018, 130, 12-21. [CrossRef]

40. Tsai, W.T.; Chen, J.R. Galvanic corrosion between the constituent phases in duplex stainless steel. Corros. Sci. 2007, 49, 3659-3668. [CrossRef]

41. Lo, I.H.; Tsai, W.T. Effect of selective dissolution on fatigue crack initiation in 2205 duplex stainless steel. Corros. Sci. 2007, 49, 1847-1861.

42. Femenia, M.; Pan, J.; Leygraf, G.; Luukkonen, P. In situ study of selective dissolution, of duplex stainless steel 2205 by electrochemical scanning tunnelling microscopy. Corros. Sci. 2001, 43, 1939-1951. [CrossRef]

43. Marcus, P.; Moscatelli, M. The role of alloyed Molybdenum in the dissolution and passivation of nickel-molybdenum alloys in the presence of adsorbed sulfur. J. Electrochem. Soc. 1989, 136, 1634-1637. [CrossRef]

44. Tomio, A.; Sagara, M.; Doi, T.; Amaya, H.; Otsuka, N.; Kudo, T. Role of alloyed molybdenum on corrosion resistance of austenitic Ni-Cr-Mo-Fe alloys in $\mathrm{H}_{2} \mathrm{~S}-\mathrm{Cl}$-environments. Corros. Sci. 2015, 98, 391-398. [CrossRef]

45. Wang, Y.; Singh, P.M. Corrosion Behaviour of Austenitic and Duplex Stainless Steels in Thiosulfate- and Chloride-Containing Environments. Corrosion 2015, 71, 937-944. [CrossRef] 
46. An, L.C.; Cao, J.; Wu, L.C.; Mao, H.H.; Yang, Y.T. Effects of Mo and Mn on Pitting Behavior of Duplex Stainless Steel. J. Iron Steel Res. Int. 2016, 23, 1333-1341. [CrossRef]

47. Rondelli, G.; Vicentini, B.; Cigada, A. Influence of nitrogen and manganese on localized corrosion behaviour of stainless steels in chloride environments. Mater. Corros. 1995, 46, 628-632. [CrossRef]

48. Zhang, W.; Jiang, L.Z.; Hu, J.C.; Song, H.M. Study of mechanical and corrosion properties of a Fe-21.4Cr-6Mn-1.5Ni-0.24N-0.6Mo duplex stainless steel. Mat. Sci. Eng. A 2008, 497, 501-504.

(C) 2018 by the authors. Licensee MDPI, Basel, Switzerland. This article is an open access article distributed under the terms and conditions of the Creative Commons Attribution (CC BY) license (http://creativecommons.org/licenses/by/4.0/). 